\title{
Sediment generation and soil mound denudation in areas of high-density tree throw along a river valley in the Jura Mountains, Switzerland
}

\author{
Philip GREENWOOD* (Dhttps://orcid.org/oooo-0002-3704-8329; ${ }_{\text {e-mail: philip.greenwood@unibas.ch }}$ \\ Jan BAUER (iD https://orcid.org/oooo-0oo1-9927-5730; e-mail: jan.r.bauer@web.de \\ Nikolaus J KUHN iD https://orcid.org/oooo-0003-4869-098X; e-mail: nikolaus.kuhn@unibas.ch \\ *Corresponding author \\ Physical Geography \& Environmental Change Research Group, Department of Environmental Sciences, University of Basel, \\ Klingelbergstrasse 27, Basel-4056, Switzerland
}

\begin{abstract}
Citation: Greenwood P, Bauer J, Kuhn NJ (2021) Sediment generation and soil mound denudation in areas of highdensity tree throw along a river valley in the Jura Mountains, Switzerland. Journal of Mountain Science 18(2). https://doi.org/10.1007/s11629-019-5867-z
\end{abstract}

(C) The Author(s) 2021.

\begin{abstract}
A preliminary field-based investigation was undertaken in a small $\left(<10 \mathrm{~km}^{2}\right)$ river valley located in the mountainous Jura region of northwest Switzerland. The aims of the work were to assess sediment generation and annual sediment transport rates by tree throw on forested hillslopes, and to document surface hydrology characteristics on four fresh soil mounds associated with recent tree throws over a 24-day monitoring period. For the soil mounds, average sediment recovery ranged from 7.7-28.2 g (dry weight), equivalent to a suspended sediment concentration of 145.2-327.8 $\mathrm{g} \mathrm{L} \mathrm{L}^{-1}$, and runoff coefficients ranged from 1.0\%-4.2\%. Based on a soil bulk density value of $1,044 \mathrm{~kg} \mathrm{~m}^{-3}$, upslope runoff generation areas were denuded by an average 0.14 $\mathrm{mm}$ by the end of the 24-day monitoring period, representing an erosion rate equivalent to $2.1 \mathrm{~mm} \mathrm{yr}^{-1}$. A ca. $50 \mathrm{~cm}$ high soil mound could therefore feasibly persist for around 200-250 years. For tree throw work, the dimensions of 215 individual tree throws were measured and their locations mapped in 12 separate locations along the river valley representing a cumulative area equivalent to 5.3 ha (av. density, 43
\end{abstract}

\footnotetext{
Received: $16-\mathrm{Nov}-2019$

$\mathbf{1}^{\text {st }}$ Revision: 04-Feb-2020

$2^{\text {nd }}$ Revision: 24-Aug-2020

$3^{\text {rd Revision: 03-Dec-2020 }}$

Accepted: $17-\mathrm{Dec}-2020$
}

per ha). Tree throws generated a total of $20.1 \mathrm{~m}^{3}$ of fine-sediment ( $<2 \mathrm{~mm}$ diameter), or the equivalent of $3.8 \times 10^{-4} \mathrm{~m}^{3} \mathrm{~m}^{-2}$. The process of tree throw was originally attributed to two extreme weather events that occurred in west and central Europe in late December 1999. Taking the 18 -year period since both storms, this represents an annual sediment transport rate of $2.7 \times 10^{-5} \mathrm{~m}^{3} \mathrm{~m}^{-1} \mathrm{yr}^{-1}$. Exploring the relationship with wind on fall direction, $65.5 \%$ of tree throws (143) generally fell in a downslope direction irrespective of hillslope aspect on which they were located. This infers that individual storms may not have been responsible for the majority of tree throws, but instead, could be associated with root failure. Given the high density of tree throws and their relative maturity (average age 41 years), we hypothesise that once trees attain a certain age in this river valley, their physiognomy (i.e. height, mass and centre of gravity) compromises their ability to remain securely anchored. We tentatively attribute this possibility to the presence of bedrock close to the surface, and to the shallow soil profile overlaying steep hillslopes.

Keywords: Tree throw; Hillslope processes; Sediment generation mechanism; Sediment transport rate; Soil mound; Ibach river valley 


\section{Introduction}

Sediment that has been detached from the parent soil by biological organisms is recognised as important driver of geomorphic and landscape modification processes in forested drainage basins (Dietrich et al. 1982; Roering et al. 2010). In particular, the mechanism of tree throw, which is defined as the sudden upheave of roots, rocky fragments and fine-sediment as the tree topples over (Gallaway et al. 2009; Hellmer et al. 2015), represents a dominant near-surface mechanism that liberates sediment from the parent soil, which thereafter can facilitate its downslope transportation on hillslopes (Gabet et al. 2003). Uprooting of trees occurs when lateral forces pushing on the tree crown and/or trunk exceed the ability of the roots and bulk soil to maintain a firm anchorage (Gabet et al. 2003). Tree throw can occur either through natural mortality, or prematurely by external factors, such as snow and ice accumulating in the crown, or a larger tree falling against a nearby smaller tree (Hellmer et al. 2015). Arguably, however, one of the most common mechanisms of tree throw is by storms (Constantine et al. 2012). Intense or prolonged rainfall before or during storms can saturate the surrounding soil, causing a tree to become unstable (Mitchell 2013). If combined with high wind, the tree can be rendered vulnerable to sudden uprooting (Peltola et al. 1999). This effect is often exacerbated in summertime when deciduous trees are in full leaf, as the high surface area of leaves increases drag and stress forces on the tree trunk as the wind passes through the canopy, whereupon stresses are then transferred down through the trunk to the roots (Constantine et al. 2012).

When a tree falls, roots, soil and rock fragments are typically upheaved as a single unit known as a root plate in a process that Gallaway et al. (2009) describe as sediment disturbance. Remnant landscape features arising from an upheaved root plate typically include a soil pit, from which the root plate has originated, and a soil mound, which is formed by rocky fragments and fine-sediment falling from the disintegrating root plate (Gallaway et al. 2009). Research undertaken by, for instance, Norman et al. (1995), Evarham and Brokaw (1996), Schaetzl et al. (1988), Pawlik (2013) and Hellmer et al. (2015) all attribute the volume of soil upheaved during a tree throw event to a number of factors that include the species, age and size of a tree, root depth and architecture, whether the tree was alive, dead or decaying at the time upheave occurred, as well as slope gradient (Norman et al. 1995), depth of soil profile, soil textural characteristics, and antecedent soil moisture content when the tree fell (Mitchell 2012).

The angle at which a tree falls relative to the steepest downslope gradient is also considered important with regard to sediment generation (Gabet et al. 2003), as it controls where on the hillslope sediment from the upheaved root plate falls relative to the soil pit (Bobrovsky and Lyko 2016). The fall direction of a tree is determined by localised factors that include hillslope gradient, hillslope contour, depth of soil profile, root depth and architecture, and prevailing wind direction. If a tree falls directly upslope (i.e. at an angle of $180^{\circ}$ relative to the steepest downslope gradient), it is likely that fine-sediment from the root plate will fall back into the soil pit, whereupon the net downslope migration of detached material will effectively be zero (Gallaway et al. 2009). Conversely, if a tree falls directly downslope, an assumption is made that sediment from the root plate will fall onto the downslope edge of the pit to form a mound. As the mound will likely consist of a mixture of brecciated rock fragments, root material and loose fine-sediment, a proportion of that sediment is rendered vulnerable to downslope migration processes (Norman et al. 1995).

Numerous approaches have been undertaken to quantify sediment flux by tree throw. Gabet et al. (2003), for instance, sought to quantify sediment detachment $\left(q_{\mathrm{s}}\right)$ by tree throw at the event scale, albeit theoretically, as a function of those hillslope characteristics shown in Eq. 1:

$$
q_{\mathrm{s}}=\frac{\text { vol }}{\text { event }} \times \frac{\text { distance }}{\text { event }} \times \frac{\text { event }}{\text { area }} \times \frac{\text { event }}{\text { time }}
$$

The longer-term net sediment transport distance $\left(X_{n}\right)$ is then estimated using Eq. 2:

$$
X_{n}=\frac{2}{\pi}(W+D) \sin \theta
$$

where $W$ is the root plate width (m), and $D$ is the root plate depth (m). More recently, both Gallaway et al. (2009) and Hellmer et al. (2015) calculated sediment transport within a known area and on a known hillslope gradient using a simplified version of a diffusion equation, where movement of sediment by tree throw is a slow, yet quasi-continuous process and dependent on hillslope gradient. The original formula, reported by Martin and Church (1997) is based 
around a modified version of Eq. 1, which is described in Eq. 3:

$$
q_{\mathrm{s}}=\frac{\sum\left(V_{\mathrm{m}} d\right)}{A_{\mathrm{p}} t}
$$

where $q_{\mathrm{s}}$ is sediment transport rate $\left(\mathrm{m}^{3} \mathrm{~m}^{-1} \mathrm{a}^{-1}\right), V_{\mathrm{m}}$ is the volume of sediment disintegrating from the root plate $\left(\mathrm{m}^{3}\right)$ and forming a soil mound, $d$ is linear transport distance (m), $A_{\mathrm{p}}$ is the area of the surveyed hillslope plot $\left(\mathrm{m}^{2}\right)$, and $t$ is the estimated time (yrs.) since the tree fell. More recently still, Strzyżowski et al. (2018) combined mapping and satellite imagery techniques applied at the regional scale to calculate sediment transport by tree throw during a single storm event using a modified version of Eq. 2.

Despite the dominance of tree throw as an ongoing sediment detachment mechanism, and hence a key determinant of forest regeneration and an important geomorphic process on hillslopes in forested landscapes (Dietrich et al. 1982; Roering et al. 2010), a review of relevant studies from 1940 to 2009 by Šamonil et al. (2010) drew attention to the fact that much research has generally focused on forested areas of North America, Russia, and northeast Europe. In contrast, and to the best of our knowledge, the effect of tree throw on sediment detachment and subsequent migration of the detached material on forested hillslope areas of central Europe that frequently experience high magnitude storm events, such as Switzerland, remains largely unstudied. This investigation seeks to redress this information shortfall by; 1), quantifying sediment detachment by tree throw and downslope migration of the detached sediment within a small catchment in the Jura Mountain Range of northwest Switzerland (central Europe), 2), quantifying erosion rates from fresh soil mounds associated with recent tree throws and 3), contribute to gaining an improved understanding of fine-sediment dynamics within a forested river valley in the Jura Mountain range.

\section{Materials and Methods}

\subsection{Jura Mountain Range}

The Jura Mountains are a subalpine range located to the north of the western Alps and straddle the border between Switzerland and France. They extend in a north-easterly to south-westerly arc, from northwest Switzerland, and terminate approximately
$200 \mathrm{~km}$ to the south, representing a total area > $22,000 \mathrm{~km}^{2}$ (Burnand et al. 1990). With a minimum elevation of ca. $200 \mathrm{~m}$ asl and a maximum elevation of $1,720 \mathrm{~m}$ asl, landscape in the Jura mountain region is heavily dissected by many now geomorphologically under-fit streams that have incised down through the limestone bedrock since the last ice age to form myriad small sub-catchments (Greenwood et al. 2014, 2018). The central part of the Jura Mountains forms a watershed that separates the Rhone and Rhine River catchments; with watercourses in the southern Jura draining into the Rhone system, and those in the northern Jura draining into the Rhine system. The landscape is characterised by steep-sided valleys and narrow floodplains overlooked by exposed rock promontories. Valley sides, although usually steep, are typically densely forested and support a mixture of European beech (Fagus sylvatica), maple (Acer platanoides), Scots pine (Pinus sylvestris) and spruce (Picea Spp.) (Greenwood and Kuhn 2014). Soil type is classified as a rendzina sensu stricto, but the presence of a coarse talus fraction in the form of brecciated limestone fragments can often account for $>50 \%$ of the soil profile by volume (Burnand et al. 1990). Whilst the soil profile may therefore be deep in places, the amount of fine (i.e. $<2 \mathrm{~mm}$ dia.) substrate is often limited and fertility of the calcareous soil is inherently low. The upper plateaux in the northern (Swiss) part of the Jura Mountains remain relatively undeveloped, with extensive agriculture in the form of fodder and hay production for small-scale cattle rearing representing the predominant land use.

\subsection{Study site}

The investigation was undertaken in a ca. $10 \mathrm{~km}^{2}$ sub-catchment known as Kaltbrunnental, situated approximately $20 \mathrm{~km}$ south of the city of Basel, in northwest Switzerland (coordinates: $47^{\circ} 25^{\prime} 09.80^{\prime \prime} \mathrm{N}$; $07^{\circ} 34^{\prime} 24.19^{\prime \prime}$ E to $47^{\circ} 25^{\prime} 46.38^{\prime \prime} \mathrm{N} ; 07^{\circ} 34^{\prime} \mathrm{O} 8.68^{\prime \prime} \mathrm{E}$ ) (Fig. 1). A more detailed description of the catchment is provided in Greenwood and Kuhn (2014) and in Greenwood et al. (2018). In brief, Kaltbrunnental is considered typical of other sub-catchments within the northern part of the Jura Mountains, inasmuch as it is deeply incised and characterised by steep valley-sides and narrow (i.e. frequently $<25 \mathrm{~m}$ wide) floodplains. The catchment is generally orientated in a north/ south direction (Fig. 1) and is drained by a small watercourse known as the Ibach, which, from source 


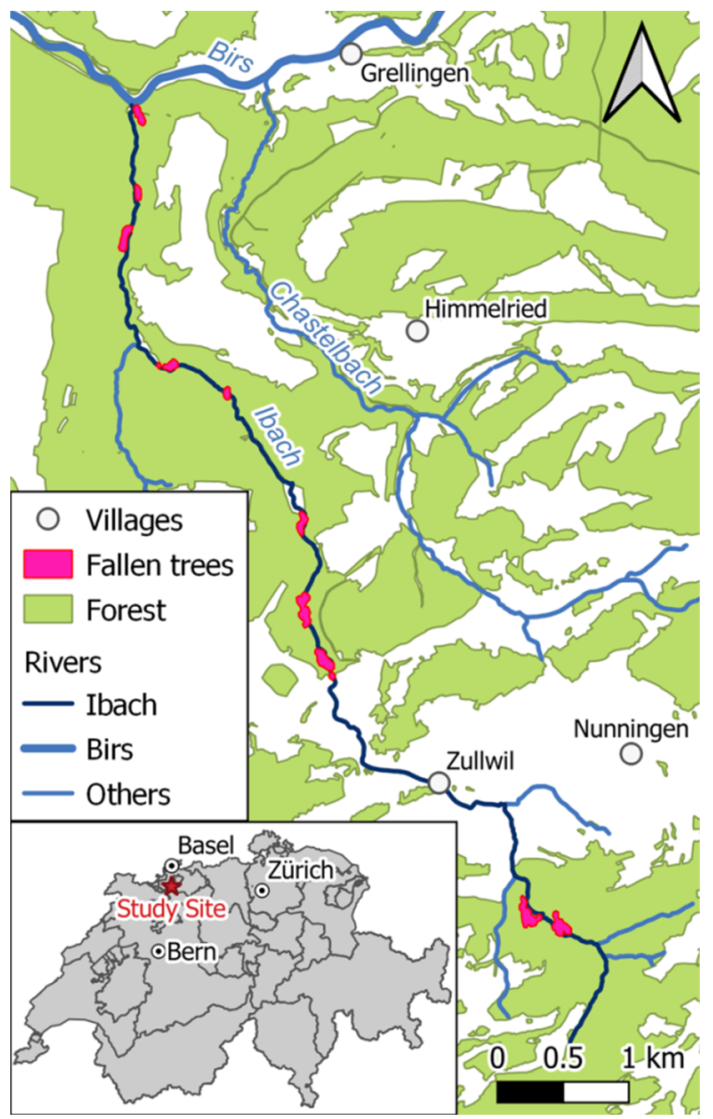

Fig. 1 Map showing the location of the study site in northwest Switzerland, along with key boundaries and features within the chosen catchment.

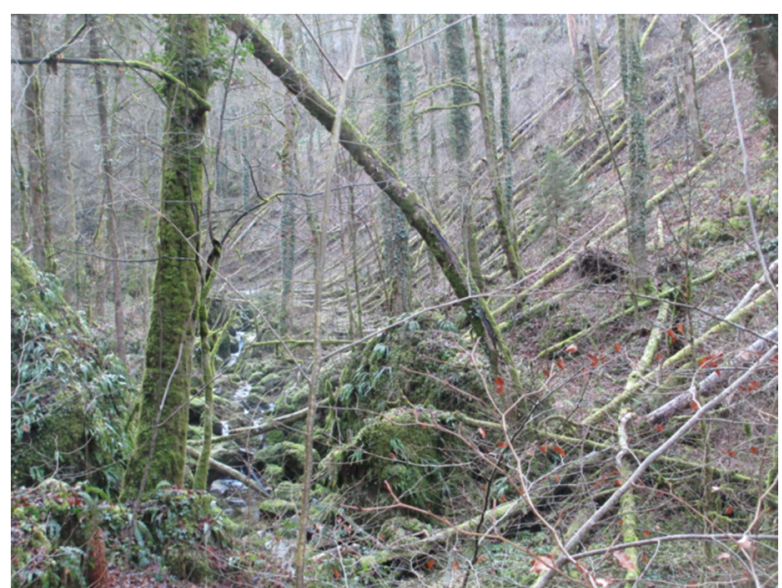

Fig. 2 Tree throws located on an east-facing hillslope adjacent to the Ibach River in Kaltbrunnental catchment.

to confluence is ca. $10 \mathrm{~km}$ long.

Average catchment elevation on the valley bottoms is ca. $500 \mathrm{~m}$ asl (max. peak, ca. $980 \mathrm{~m}$ asl) and the climate is defined as temperate humid, with a mean maximum daily temperature of $25^{\circ} \mathrm{C}$ (August) in summer, and a mean minimum daytime temperature of $-1^{\circ} \mathrm{C}$ (January) in winter. Average annual precipitation is ca. $1,100 \mathrm{~mm}$ and average peak monthly rainfall, at $99 \mathrm{~mm}$, occurs in May (FOMC MeteoSwiss 2014). From late November until around mid-March, low temperatures mean that precipitation can often fall as snow where it frequently accumulates and can remain until late-March. The steep valley sides, combined with the prominence of bedrock typically limit soil profile depth to $<40 \mathrm{~cm}$. Forests within Kaltbrunnental are prevalent on valley sides and mainly consist of $F$. sylvatica, interspersed with small, isolated stands of $P$. sylvestris. Whilst understory vegetation is generally sparse to absent on the upper valley sides, the lower hillslopes are usually covered with a notable layer of dead and decaying leaf litter

Reasons for choosing this catchment arose whilst undertaking other longer-term sediment-related monitoring work (see Greenwood and Kuhn 2014, and Greenwood et al. 2018, 2019) which necessitated conducting regular fieldwork campaigns. During site visits, the observed abundance of fallen trees, such as those seen in Fig. 2, the apparent recurrence of tree throw, and the level of lateral sediment connectivity that exists between steep valley sides, narrow floodplains and river channel (Fryirs et al. 2007) all provided motivation to undertake a preliminary investigation to quantify if, and by how much, tree throw acts as a sediment generation mechanism, defined here as the detachment of fine material from the parent soil by uprooting, and to make a provisional assessment of the annual migration rate of the detached (fine) material. Although most studies investigating tree throw tend to focus on both coarse and fine material, we specifically focus only on the latter of those size-fractions (i.e. $<2 \mathrm{~mm}$ dia.) for three key reasons. Firstly, its small physical size makes it the most easily erodible of all fractions. Secondly, fine-sediment carries exceptionally high concentrations of nutrients and contaminants (Walling et al. 2003) which, if entering nearby rivers and streams, can cause pollution and thus reduce water quality (Horowitz et al. 2012). Thirdly, the characteristically narrow floodplains (i.e. $<25 \mathrm{~m}$ wide) along the Ibach river, and other sub-catchments in the Jura region, offer limited opportunity for deposition and storage of eroded fine-sediment. From a geomorphological perspective, therefore, narrow floodplains directly elevate the lateral connectivity that links valley-sides to the river channel, and 
thereby increase the likelihood that a portion of the eroded fine-sediment will enter the river, perhaps within seasonal timescales. Unlike some other studies, we do not consider brecciated rock fragments upheaved by tree throw, as an absence of such material on cleared tracks and pathways at the base of valley sides indicated that this fraction was largely immobile and relatively stable, despite the steep slopes on which it occurs, presumably due to their angular and interlocking shape.

\subsection{Field methods: assessing sediment mobility on recently-formed soil mounds}

Intrigued by the abundance of tree throws, and inquisitive about their potential as a sediment generation mechanism, a runoff trap was installed in October 2015 on a soil mound associated with four recent ( $<6$ month) tree throws. The four soil mounds were all considered recent topographic features for three reasons. Firstly, some tree throws still carried leaves from the previous summer growth. Secondly, residual plumes of fine-sediment were readily visible downslope from each mound, and thirdly, established (i.e. rooted) vegetation was completely absent on each mound. Measurements of sediment mobilisation were physically obtained using runoff traps, each of which were fabricated from two $38 \mathrm{~cm}$ wide $\times 15 \mathrm{~cm}$ long $\times 3$ $\mathrm{cm}$ deep plastic trays, of the type ordinarily used to stand/water indoor plants in. The side-wall along the length of each tray was firstly cut away and removed to create an elongated opening. A trap was constructed by presenting a pair of trays together, top-to-top, with the cutaway portion creating a narrow opening, which was designed to allow runoff and sediment to freely enter, but keep out any form of precipitation. Once assembled, the remaining edges of each tray were sealed with bathroom silicon gel to form a watertight seal. Ordinary elastic bands were then carefully bound around the length and width of each trap for added strength and stability, and also to facilitate rapid ease of access when recovering runoff and associated sediment during site visits. Once assembled, each runoff trap was then embedded at the base, and on the down-valley side of a soil mound, flush with the soil surface, with the cutaway opening facing upslope. Traps were then held in place using a series of wooden pegs driven into in the soil profile immediately downslope of each trap, to prevent downslope movement of the trap itself. As an added measure, each trap was also carefully weighted down with rocks to prevent disturbance by wind or animals. The above configuration and the upslope runoff generation area can be seen in Fig. 3.

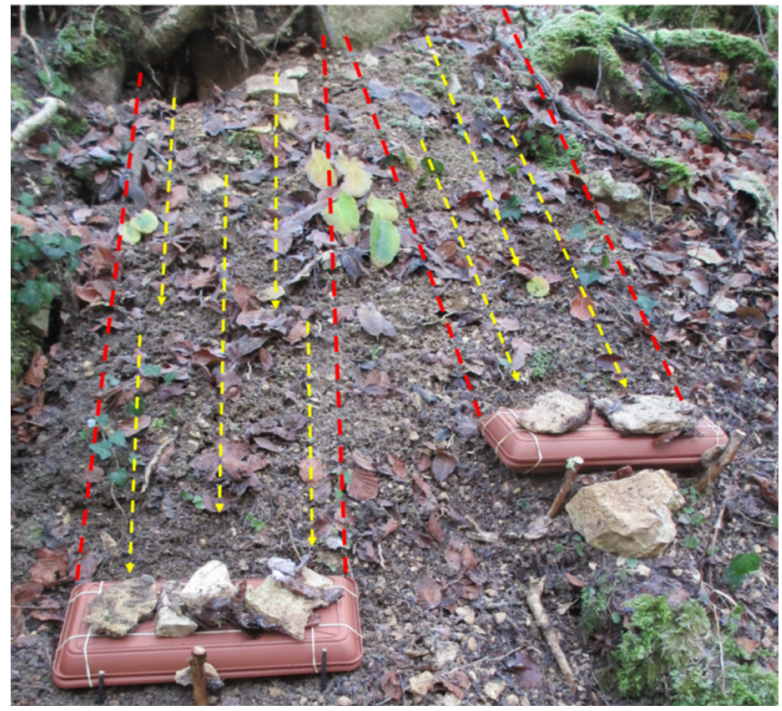

Fig. 3 Sediment traps were positioned at the base of fresh soil mounds on the down-valley side and kept in place using wooden pegs and stone weights. Upslope runoff generation areas are depicted in red dashed lines, and possible flow-paths depicted in yellow dashed arrows.

Soil mound characteristics were documented and included the angle of repose, which we use as a proxy for, and hereafter refer to as slope gradient, upslope length and runoff generation area immediately upslope of each runoff trap. Cumulative rainfall was recorded between site visits using an automated EM50 data logger $\left(\mathrm{ECH}_{2} \mathrm{O}\right.$ System; Meter Group, USA) which was installed away from the tree canopy but central to the study area. A total of four site visits were made (not including trap installation), and the time-interval between visits ranged from three to 14 days (24-day total) depending on the amount of rainfall. The resultant data were used to estimate runoff coefficients (\%), and quantities of recovered sediment, expressed as both (dry) mass (g) and equivalent suspended sediment concentration (SSC) ( $\left.\mathrm{g} \mathrm{L}^{-1}\right)$.

\subsection{Field methods: mapping three throws}

Field walking was initially undertaken along the length of the Ibach to identify candidate areas. Twelve areas were identified, all of which were located within the Ibach River valley which, from the perspective of 
sediment connectivity and fine-sediment migration, meant that they were directly geomorphologically linked to the river (Fryirs et al. 2007). Importantly, most (i.e. 95\%) of the tree throws that could be safely accessed and mapped without using specialised safety equipment were located within these sites. The remaining $5 \%$ of tree throws located on slopes that were either too steep, or too close to vertical cliff edges were considered too dangerous to access and were thus not mapped. Hillslope aspect was determined for all sites using a standard fieldcompass, and individual tree throws were mapped following a combination of general field protocols described in Galloway et al. (2009) and Hellmer et al. (2015). Mapping initially involved recording the coordinates of each fallen tree using a GPS (Swiss Coordinate System: $\mathrm{CH}_{1903}+$ ). Individual tree throw dimensions were recorded and included height, width and depth of the root plate, as well as tree trunk diameter measured $1.5 \mathrm{~m}$ from the base of the trunk (hereafter referred to as 'diameter at breast height' $(\mathrm{DBH}))$. The DBH measurements enabled the circumference of the trunk to be established, and inturn, provided a means of approximating the age of a tree at the time it fell using a method established by Mitchell (1974) for aging trees in northwest Europe. Although this represents a very basic yet rapid technique, it was considered appropriate for this preliminary investigation, but we acknowledge that it does not take into account localised environmental controls that govern individual tree growth, or other factors such as inter- and intra-specific competition between neighbouring trees (Schweingruber 2007). Given these potential shortcomings, we emphasis, therefore, that ages of tree throws represent approximations only.

Other documented parameters included hillslope gradient at the location of each tree throw, and the angle of [fall] obliquity relative to the direct downslope gradient. In-situ soil bulk density measurements $(n=36)$ were taken at hillslope sites, at depths ranging from $10-40 \mathrm{~cm}$ in the soil profile in order to convert estimates of sediment transport volume $\left(\mathrm{m}^{3}\right)$ to equivalent mass $\left(\mathrm{kg} \mathrm{m}^{-3}\right)$.

On tabulating the acquired data, a first step was to establish the area of each site. This was achieved by overlaying GPS coordinates for each tree throw onto relevant topographic maps displayed in a Geographical Information System (GIS) (ArcGIS, version 10.3; Environmental Systems Research
Institute (ESRI)). A polygon was drawn around tree throws in each mapped location and those located at the periphery of the main cluster were used as boundaries by which the area of each polygon was calculated. The second analytical step involved determining the root plate volume of tree throws. These were estimated using the half-ellipsoid model originally developed by Denny and Goodlet (1956), and latterly used by both Norman et al. (1995) and Gallaway et al. (2009), and which included brecciated rock fragments, root material, and soil pore space, as well as fine-sediment fraction. As only the latter portion is of interest to this investigation, field observations made at the time of mapping suggested we should conservatively attribute a nominal $25 \%$ of a total root plate volume to fine-sediment, which is estimated using Eq.4:

$$
V_{\mathrm{S}}=0.25 \times V_{\mathrm{RP}}
$$

where $V_{\mathrm{S}}$ is the volume of detached fine-sediment $\left(\mathrm{m}^{3}\right), \quad 0.25$ is the proportion of fine-sediment attributed to the total root plate volume $\left(V_{\mathrm{RP}}, \mathrm{m}^{3}\right)$.

Sediment transport distance was calculated using a geometric approach adopted by both Gabet et al. (2003) and Hellmer et al. (2015), which is described in Eq. 5:

$$
X_{d}=W / 2(\cos \theta+\sin \theta)+D / 2(\sin \theta-\cos \theta)
$$

where $X_{\mathrm{d}}$ is downslope sediment transport distance (m), $\theta$ is the hillslope gradient (deg.), and $W$ and $D$ represent the width and depth (m) of the root plate, respectively. As Eq. 5 determines maximum sediment transport generated by a tree falling directly downslope, it was necessary to account for tree throws falling oblique to the downslope gradient. Values for $X_{\mathrm{d}}$ were thus modified, where required, using Eq. 6:

$$
d=\left(\left|180^{\circ}-\alpha\right|\right) \frac{x_{\mathrm{d}}}{180^{\circ}}
$$

where $d$ is the modified sediment transport distance value (m), and $\alpha$ is the oblique fall direction (deg.). If a tree falls directly upslope, fall direction, $\alpha=180^{\circ}$, and sediment transport, $d=0$, as this approach assumes that all upheaved sediment will return to the soil pit. By contrast, when a tree falls directly downslope, $\alpha=\mathrm{O}^{\circ}$ and $d=X_{\mathrm{d}}$.

In a final stage, sediment transport rate was calculated using a similar model as Hellmer et al. (2015), and which is described in Eq. 7:

$$
q_{\mathrm{s}}=\sum\left(V_{\mathrm{S}} d\right) /(A t)
$$

where $q_{\mathrm{s}}$ is the sediment transport rate $\left(\mathrm{m}^{3} \mathrm{~m}^{-1} \mathrm{yr}^{-1}\right), A$ 
is the mapped area $\left(\mathrm{m}^{2}\right)$, and $t$ is the time interval (yrs.) required to generate the number of tree throws mapped. As this study represents a preliminary assessment of sediment generation potential by treethrow, we present sediment detachment and transport rates for individual mapped areas in order to provide an indication of localised detachment rates which may be related to topographic or other environmental factors (Mitchell 2012). Further to this, as the timing of individual tree throws in Kaltbrunnental is not known, we apply a time interval of $t=18$ yrs. (i.e. 1999), as this corresponds with the elapsed period between when this study was conducted (2017), and two extreme weather events that swept across west and central Europe on $26^{\text {th }}$ and $28^{\text {th }}$ December 1999, and referred to as Storms Lothar and Martin, respectively. We hypothesise that exceptionally high winds during these two storms acted as a detachment 'trigger' that initiated treethrow, which in-turn upheaved and liberated finesediment from the soil profile, thus rendering it vulnerable to varying downslope migration processes (Constantine et al. 2012). Those processes considered most important in this catchment include diffusive soil creep (Martin 2000; Hellmer et al. 2015), raindrop-impact-induced displacement (Kinnell 2005; Gallaway et al. 2009; Geißler et al. 2012), rainfallgenerated surface runoff (Greenwood and Zhang 2020), and freeze-thaw/snowmelt (Hayhoe et al. 1993). In terms of storm intensity, the Saffir-Simpson Scale, which is commonly used to measure storm intensities in tropical regions estimated Storms Martin and Lothar as weak and moderately-strong hurricanes, respectively. Based on European windstorm records for the last century, Storm Lothar was estimated to be a one in 100-year event, and Storm Martin a one in 50-year event (EQE Consulting 2020). In the northern Jura region, including our study catchment, sustained gusts $>49 \mathrm{~m} \mathrm{~s}^{-1}\left(175 \mathrm{~km} \mathrm{~h}^{-1}\right)$ were recorded during both storms, resulting in the premature loss of between $5^{-15} \mathrm{~m}^{3} \mathrm{ha}^{-12}$ of timber due to tree throw (Bründl and Rickli 2002). We do not average sediment generation and migration rates across equivalent storm return frequencies because, firstly, no storm events of a similar magnitude have occurred since 1999. Secondly, soil creep operates constantly under gravity, and works in tandem with precipitation-driven erosive events which are recurrent in this region, with multiple events often taking place each month (Ledermann et al. 2008), making their relative erosivity magnitude too numerous to document individually.

\section{Results}

\subsection{Erosion of soil mounds}

The gradient of the four soil mounds ranged from $35^{\circ}-56^{\circ}$ (ca. $71 \%-147 \%$ ), slope length immediately upslope of each runoff trap ranged from 0.45-1.6 m, and runoff generation areas corresponding with the width of the runoff trap and up to the uppermost part of the soil mound ranged from 0.17-0.61 $\mathrm{m}^{2}$. Cumulative rainfall between visits was 15, 17, 19.1 and $5 \mathrm{~mm}$ for site visits $1-4$, respectively. Runoff and sediment were recovered from all traps during all four visits and key results are listed in Table 1. Data from the four traps were averaged per site visit and the mass of recovered sediment (dry) ranged from 7.7$28.2 \mathrm{~g}$. Sediment recovery values were converted to equivalent SSC and ranged from 145.2-327.8 $\mathrm{g} \mathrm{L}^{-1}$. Runoff coefficients ranged from 1.0\%-4.2\%. Based on data from all four traps over all site visits, a weak direct correlation was obtained between sediment recovery (g) and \% runoff coefficient $\left(r^{2}=0.15\right)$, which was not significant at the $95 \%$ confidence level, and a moderately strong direct correlation $\left(r^{2}=0.77\right)$ was obtained between sediment recovered $(\mathrm{g})$ and equivalent $\mathrm{SSC}\left(\mathrm{g} \mathrm{L}^{-1}\right)$, which was significant at the 95\% confidence level. Based on the cumulative amounts of sediment recovered from each soil mound over the 24-day monitoring period, using a bulk density (BD) equivalent to $1,044 \mathrm{~kg} \mathrm{~m}^{-3}$, we estimate that the soil surface of the four mounds, for the upslope areas where measurements were taken, was denuded by an average of $0.14 \mathrm{~mm}$, or the equivalent of $2.1 \mathrm{~mm} \mathrm{yr}^{-1}$. Given the prominence of soil mounds above the soil surface and their exposure to a large range of degradation processes (Martin et al. 2013), we assume this rate of erosion is likely to be applicable over the entire surface of each fresh soil mound.

\subsection{Mapped tree throw sites: descriptive statistics}

Tree throws were mapped in 12 discrete areas (hereafter referred to as Sites a-l) along the Ibach River valley where most tree throws were located. Key 
Table 1 Results of surface hydrology measurements using runoff sediment traps installed on four soil mounds, each under a recent tree throw (us means upslope, ds means downslope, L means left, $\mathrm{R}$ means right)

\begin{tabular}{|c|c|c|c|c|c|c|c|c|c|c|c|}
\hline \multirow{2}{*}{$\begin{array}{l}\text { Site } \\
\text { Visit }\end{array}$} & \multirow{2}{*}{$\begin{array}{l}\text { Runoff } \\
\text { trap ID }\end{array}$} & \multirow{2}{*}{$\begin{array}{l}\text { Angle of } \\
\text { repose (o) }\end{array}$} & \multirow{2}{*}{$\begin{array}{l}\text { Slope } \\
\text { length } \\
\text { (m) }\end{array}$} & \multirow{2}{*}{$\begin{array}{l}\text { Runoff } \\
\text { generation } \\
\text { area }\left(\mathrm{m}^{2}\right)\end{array}$} & \multirow{2}{*}{$\begin{array}{l}\text { Cumulative } \\
\text { rainfall } \\
\text { (mm) }\end{array}$} & \multicolumn{2}{|c|}{$\begin{array}{l}\text { Sediment } \\
\text { recovery }(g)\end{array}$} & \multicolumn{2}{|c|}{$\begin{array}{l}\text { Suspended sediment } \\
\text { concentration }\left(\mathrm{g} \mathrm{L}^{-1}\right)\end{array}$} & \multicolumn{2}{|c|}{$\begin{array}{l}\text { Runoff } \\
\text { coefficient (\%) }\end{array}$} \\
\hline & & & & & & Value & Av. & Value & Av. & Value & Av. \\
\hline \multirow{4}{*}{ 1st } & 1us & 40 & 1.6 & 0.61 & \multirow{4}{*}{15} & 5.7 & \multirow{4}{*}{9.7} & 149.1 & \multirow{4}{*}{238.7} & 0.5 & \multirow{4}{*}{1.1} \\
\hline & $2 \mathrm{ds}$ & 56 & 0.45 & 0.17 & & 4.4 & & 104.2 & & 2.5 & \\
\hline & $3 \mathrm{~L}$ & 35 & 1.37 & 0.52 & & 21.2 & & 532.7 & & 0.6 & \\
\hline & $3 R$ & 38 & 1.3 & 0.49 & & 7.4 & & 168.7 & & 0.7 & \\
\hline \multirow{4}{*}{ 2nd } & 1us & 40 & 1.6 & 0.61 & \multirow{4}{*}{17} & 9.0 & \multirow{4}{*}{9.3} & 86.3 & \multirow{4}{*}{178.1} & 1.1 & \multirow{4}{*}{1.3} \\
\hline & $2 \mathrm{ds}$ & 56 & 0.45 & 0.17 & & 7.1 & & 141.5 & & 2.6 & \\
\hline & $3 \mathrm{~L}$ & 35 & 1.37 & 0.52 & & 12.8 & & 323.5 & & 0.6 & \\
\hline & $3 R$ & 38 & 1.3 & 0.49 & & 8.3 & & 161.3 & & 0.7 & \\
\hline \multirow{4}{*}{3 rd } & 1us & 40 & 1.6 & 0.61 & \multirow{4}{*}{19.1} & 8.5 & \multirow{4}{*}{7.7} & 66.5 & \multirow{4}{*}{145.2} & 1.3 & \multirow{4}{*}{1.0} \\
\hline & $2 \mathrm{ds}$ & 56 & 0.45 & 0.17 & & 6.3 & & 224.3 & & 1.3 & \\
\hline & $3 \mathrm{~L}$ & 35 & 1.37 & 0.52 & & 9.8 & & 171.8 & & 0.7 & \\
\hline & $3 R$ & 38 & 1.3 & 0.49 & & 6.3 & & 118.0 & & 0.7 & \\
\hline \multirow{4}{*}{ 4th } & 1us & 40 & 1.6 & 0.61 & \multirow{4}{*}{5} & 62.1 & \multirow{4}{*}{28.2} & 540.7 & \multirow{4}{*}{327.8} & 4.3 & \multirow{4}{*}{4.2} \\
\hline & $2 \mathrm{ds}$ & 56 & 0.45 & 0.17 & & 6.4 & & 203.4 & & 5.5 & \\
\hline & $3 \mathrm{~L}$ & 35 & 1.37 & 0.52 & & 37.9 & & 467.3 & & 3.9 & \\
\hline & $3 R$ & 38 & 1.3 & 0.49 & & 6.4 & & 99.7 & & 3.1 & \\
\hline
\end{tabular}

Table 2 Key descriptive information associated with mapped tree throws in 12 surveyed areas in Kaltbrunnental subcatchment in the Jura Mountains

\begin{tabular}{|c|c|c|c|c|c|c|c|c|c|c|c|c|c|c|}
\hline Area ID & a & $\mathrm{b}$ & $\mathrm{c}$ & d & $\mathrm{e}$ & $\mathrm{f}$ & $\mathrm{g}$ & $\mathrm{h}$ & i & $\mathrm{j}$ & $\mathrm{k}$ & 1 & Total & Av. \\
\hline Surveyed area (ha) & 0.21 & 0.60 & 0.15 & 0.26 & 0.35 & 0.16 & 0.33 & 0.50 & 0.82 & 0.90 & 0.57 & 0.45 & $5 \cdot 3$ & $\mathrm{n} / \mathrm{a}$ \\
\hline Numbers of tree throws & 10 & 29 & 8 & 10 & 13 & 8 & 12 & 24 & 40 & 20 & 22 & 19 & 215 & $\mathrm{n} / \mathrm{a}$ \\
\hline Tree throw density $\left(h^{-1}\right)$ & 48 & 48 & 53 & 39 & 37 & 50 & 36 & 48 & 49 & 22 & 39 & 42 & $\mathrm{n} / \mathrm{a}$ & 43 \\
\hline Av. slope $\left(^{\circ}\right)$ & 28 & 30 & 34 & 40 & 20 & 31 & 38 & 40 & 36 & 28 & 34 & 27 & $\mathrm{n} / \mathrm{a}$ & 32.2 \\
\hline Av.t & 33 & 38 & 30 & 39 & 42 & 39 & 39 & 24 & 25 & 26 & 34 & 38 & $\mathrm{n} / \mathrm{a}$ & 33.9 \\
\hline 1. $(\mathrm{cm})$ & 104 & 120 & 94 & 122 & 131 & 122 & 121 & 76 & 80 & 80 & 106 & 118 & $\mathrm{n} / \mathrm{a}$ & 106.2 \\
\hline Av. estimate & 42 & 48 & 38 & 49 & 52 & 49 & 48 & 30 & 32 & 32 & 43 & 47 & $\mathrm{n} / \mathrm{a}$ & 41 \\
\hline Sub-total root plate volum & 4.7 & $15 \cdot 5$ & 2.3 & 2.8 & 8.7 & 5.2 & 6.8 & 2.6 & 6.9 & 7.8 & 3.6 & 13.4 & 71.54 & 6.7 \\
\hline Sediment volume $\left(\mathrm{m}^{3}\right)$ & 1.2 & 3.9 & 0.6 & 0.7 & 2.2 & 1.3 & 1.7 & 0.6 & 1.7 & 2 & 0.9 & $3 \cdot 3$ & 20.1 & 1.7 \\
\hline
\end{tabular}

descriptive site characteristics are listed in Table 2. Mapped areas ranged from 0.15-0.90 ha, with a cumulative area equivalent to 5.3 ha. Median hillslope gradients of the 12 sites ranged from $27^{\circ}-40^{\circ}$ and the median gradient based on all sites was $35^{\circ}$. The dimensions and positions of 215 tree throws were mapped within the 12 sites, with tree throw densities ranging from an equivalent 22 per ha (Site j) to 53 per ha (Site c), with an average of 43 per ha. The volume of fine-sediment generated by tree throw at each site ranged from $0.6 \mathrm{~m}^{3}$ (Sites c \& h) to $3.9 \mathrm{~m}^{3}$ (Site b). Cumulatively, the 215 tree throws generated $20.1 \mathrm{~m}^{3}$ of fine-sediment within the 5.3 ha mapped area. Given limitations with the ageing technique outlined in the Methods section, the following ages presented in Fig. 4 represent very tentative estimates only, but range from $1-5$ yrs. old (0.5\%; $n=1)$, to $111-115$ yrs. old $(0.5 \% ; n=1)$ when upheave occurred. Peak upheave occurred when trees were estimated at between 36-40 yrs. old $(18.1 \% ; n=39)$ and the average age at time of upheave was estimated at 41 yrs. The age-range of standing trees was conservatively estimated to be at least 150 years, which contrasts with the 109-year age-range of fallen trees (youngest 5 years; oldest 114 years). Based on the younger age-range associated with tree throws, the tree throw dataset was positively skewed (1.27).

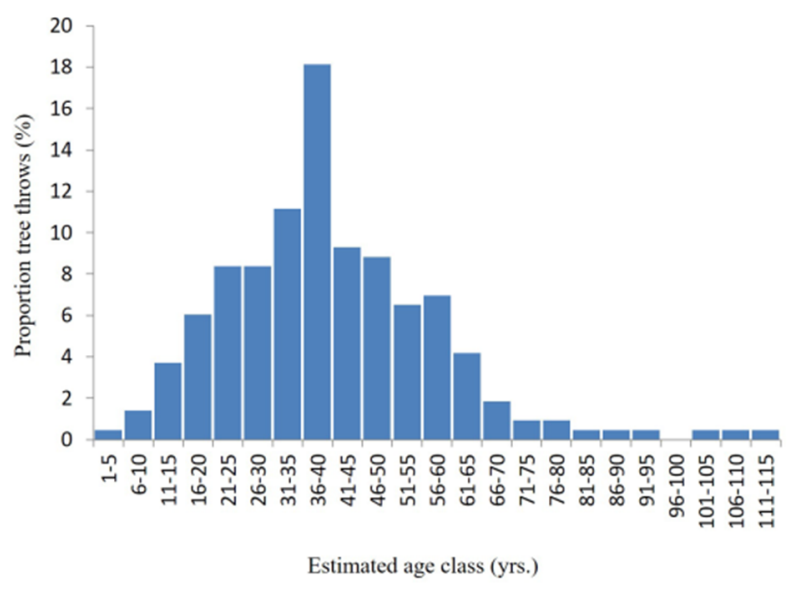

Fig. 4 Estimated age frequency of mapped tree throws. 
Tree throw fall directions, although recorded individually, were categorised for simplicity in four $90^{\circ}$ orientations; those that fell between $316^{\circ}-45^{\circ}$ (hereafter referred to as 'downslope'), those that fell between $226^{\circ}-315^{\circ}$ (left-side of slope), those that fell between $46^{\circ}-135^{\circ}$ (right-side of slope) and those that fell between $136^{\circ}-225^{\circ}$ (upslope). Presented in this general configuration and expressed as percentages of the total number ( $n=215$ ), Fig. 5 reveals that $80.5 \%$ of all tree throws (173) fell downslope, 9.8\% (21) and 7\% (15) fell to the left and right of the slope, respectively, and just 2.8\% (6) fell upslope.

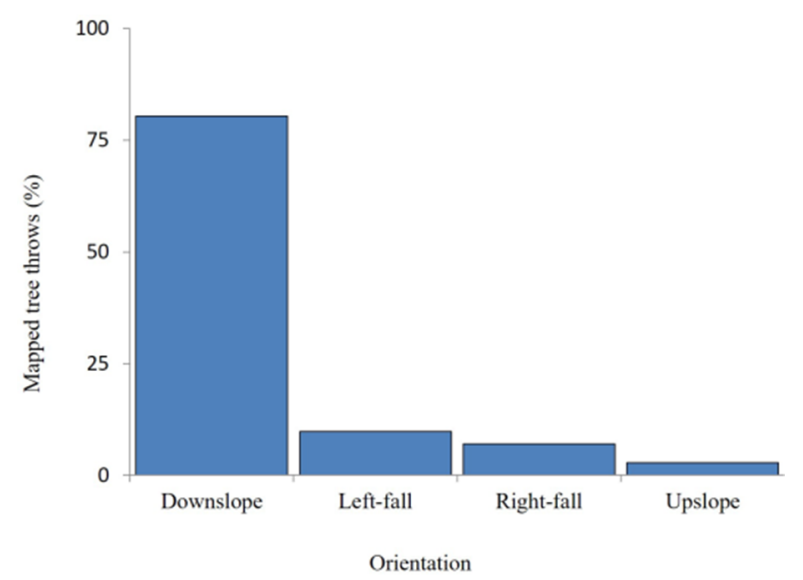

Fig. 5 Tree throw fall directions categorised into four general orientations

\subsection{Sediment generation and transport rates by tree throw}

Incorporating relevant information into Eqs. 4-7, the $20.1 \mathrm{~m}^{3}$ of fine-sediment generated within the 5.3 ha area represents a volume of soil equivalent to $3.8 \times 10^{-4} \mathrm{~m}^{3} \mathrm{~m}^{-2}$. Taking the 18 -year period since Storms Lothar and Martin, when our assumption predicts that most trees were blown over, the average annual rate of sediment generation attributed to tree throw is estimated at $2.1 \times 10^{-5} \mathrm{~m}^{3} \mathrm{~m}^{-2} \mathrm{yr}^{-1}$, or the equivalent of $2.2 \times 10^{-2} \mathrm{~kg} \mathrm{~m}^{-2} \mathrm{yr}^{-1}$, using the same BD value stated above.

Entering relevant data into Eq. 8, average sediment transport volume of soil crossing a unit width of hillslope, based on data from all 12 sites, is estimated at $4.8 \times 10^{-4} \mathrm{~m}^{3} \mathrm{~m}^{-1}$. Again, dividing this value by the 18-year period since Storms Lothar and Martin, the average annual sediment transport rate is estimated at $2.7 \times 10^{-5} \mathrm{~m}^{3} \mathrm{~m}^{-1} \mathrm{yr}^{-1}$, or the equivalent of $2.8 \times 10^{-2} \mathrm{~kg} \mathrm{~m}^{-1} \mathrm{yr}^{-1}$, using the same BD value reported earlier. A comparison of annual sediment transport rates, expressed as both volume and mass, is listed for all 12 sites in Table 3.

\section{Discussion}

\subsection{Erosion of tree throw mounds}

Surface hydrology measurements from a freshlyformed soil mound under four recent tree throws revealed very low runoff coefficients (max. $\leq 4.2 \%$ ), but very high equivalent SSC values (max. $540.7 \mathrm{~g} \mathrm{~L}^{-1}$ ). For perspective, and by way of comparison, Greenwood et al. (2018) reported a SSC of $0.54 \mathrm{~g} \mathrm{~L}^{-1}$ for the Ibach river during high flow conditions. The weak correlation between sediment recovery and \% runoff coefficient is interpreted as a strong indication that surface runoff did not play a significant role in mobilising sediment on the fresh soil mounds. The significant correlation between sediment recovery and SSC is interpreted as evidence of the loose nature of the soil, resulting in high infiltration potential, both of which would inhibit incidences of runoff generation. Although the high SSCs indicate that fine-sediment is extremely mobile, albeit at very localised spatial scales, the collective findings infer that surface runoff is not dominant in controlling downslope sediment displacement. Instead, we hypothesise that the naturally steep angle of soil mounds, along with the un-compacted nature of the material and their exposed, above-ground position all render finesediment extremely vulnerable to downslope mobilisation by processes other than surface runoff. Those processes under consideration most likely

Table 3 Sediment transport rates by tree throw within 12 surveyed areas in Kaltbrunnental in the Jura Mountains (expressed as volume and mass values).

\begin{tabular}{|c|c|c|c|c|c|c|c|c|c|c|c|c|c|}
\hline Area ID & a & $\mathrm{b}$ & $\mathrm{c}$ & d & $\mathrm{e}$ & $\mathrm{f}$ & $\mathrm{g}$ & $\mathrm{h}$ & i & $\mathrm{j}$ & $\mathrm{k}$ & l & Av. \\
\hline $\begin{array}{l}\text { Sediment transport rate since storms } \\
\text { Lothar \& Martin }\left(10^{-4} \mathrm{~m}^{3} \mathrm{~m}^{-1}\right)\end{array}$ & $5 \cdot 3$ & 7.7 & 3.6 & 3 & 4.1 & 8.8 & 6.6 & 11 & 2.1 & 2.8 & 1.5 & 10.7 & 4.8 \\
\hline $\begin{array}{l}\text { Volume sediment transport rate } \\
\left(10^{-5} \mathrm{~m}^{3} \mathrm{~m}^{-1} \mathrm{yr}^{-1}\right)\end{array}$ & 3 & $4 \cdot 3$ & 2 & 1.7 & 2.3 & 4.9 & 3.6 & 0.6 & 1.2 & 1.5 & 0.8 & 5.9 & 2.7 \\
\hline $\begin{array}{l}\text { Mass sediment transport rate } \\
\left(10^{-2} \mathrm{~kg} \mathrm{~m}^{-1} \mathrm{yr}^{-1}\right)\end{array}$ & 3.1 & 4.4 & 2.1 & 1.7 & 2.4 & 5.1 & 3.8 & 0.7 & 1.2 & 1.6 & 0.9 & 6.2 & 2.8 \\
\hline
\end{tabular}


include diffusion and soil creep of loose material by gravity, combined with, and probably exacerbated by, varying mechanisms capable of physically displacing fine sediment (Martin et al. 2013), that include the disturbance of surface material by water-driven processes such as rain-splash (Gallaway et al. 2009) and raindrop-impaction (Kinnell 2005), freeze/thaw processes, and bioturbation by animals.

Assuming a similar rate of sediment migration through time by soil creep, rain-splash, impacting raindrops (Kinnell 2005), and other water-related processes (Gallaway et al. 2009), and ignoring the influence that colonising vegetation may have on stabilising soil, our findings imply that a $50 \mathrm{~cm}$ tall mound could feasibly persist in the landscape for several centuries, although this could underestimate their true longevity, given that soil mounds will become increasingly stable as material becomes compacted and rooted vegetation binds particles and aggregates together. Despite this latter caveat in terms of their possible persistence, our findings generally corroborate the predicted longevity of soil mounds in temperate forests originally suggested by Lutz (1940) and more recently reiterated by Putz (1983), but does not support findings reported by Šamonil et al. (2013), who found that some soil mounds are able to persist for millennia under certain conditions. Such conditions included sandy soils where high infiltration of surface water presumably inhibits runoff generation and serves to prolong their preservation. Based on limited field-based evidence of pit and soil mound longevity in different forested settings, the degradation of such features was exploratorily modelled by Martin et al. (2013) on 1.0 $\mathrm{m}$ diameter mounds using diffusion coefficients of 0.1 , 0.01 and $0.001 \mathrm{~m}^{2} \mathrm{yr}^{-1}$, the results from which suggested pit and mound features could be eradicated within timescales of just a few years, to ca. 150 years. Although their wide-ranging results using varying diffusion coefficients, albeit on mounds of similar diameters to those investigated here, prevent us from drawing direct comparisons in terms of an actual erosion estimate, such as we report in this study, we pragmatically use field-based measurements of soil mound degradation reported in Martin et al. (2013) in which soil mound height diminished by an estimated $600 \mathrm{~mm}$ over a 30-year period. This represents an equivalent average erosion rate of $20 \mathrm{~mm} \mathrm{yr} .^{-1}$, which is an order of magnitude higher than the $2.1 \mathrm{~mm} \mathrm{yr}^{-1}$ rate reported by us. Given the variable results from different studies, more in-depth information of soil mound formation, and the timescales over which denudation take place, are clearly required in order to provide a reliable base from which future modelling or similar studies might be conducted. Taking the number of mapped tree throws, and attributing a nominal $1.0 \mathrm{~m}$ diameter to the base of each soil mound, we calculate that disturbance to the surface soil by tree throw accounts for $0.0063 \%$ of the area of the Ibach river valley. This is a similar order of magnitude to that reported by both Osterkamp et al. (2006) and Gallaway et al. (2009).

\subsection{Variations in tree throw density}

In order to explore which characteristics most influenced sediment transport rates in our study area, multiple regression analysis was performed at the $95 \%$ confidence level on what were considered to be four key controlling variables; namely average root plate volume, average hillslope gradient, average tree throw direction and tree throw density at each site. Results from multiple regression analyses are shown in Eq. 8:

$$
y=-4.74+9.70 x_{1}+0.09 x_{2}-0.03 x_{3}-0.002 x_{4}(8)
$$
where $y$ is the sediment transport rate, $x_{1}$ is average root plate volume, $x_{2}$ is average slope gradient, $x_{3}$ is average tree throw direction, and $x_{4}$ is tree throw density. The results seen in Eq. 8 show a coefficient of determination $\left(r^{2}\right)$ of $0.84(84 \%)$ and also indicate that average root plate volume $\left(x_{1}\right)$ represents the only variable that significantly influences sediment transport, since data output for the other three other variables, $x_{2-4}$, are all close to zero. A possible reason for the importance of root plate volume in influencing sediment transport may be due to the thin $(<40 \mathrm{~cm}$ deep) soil profile, as this constraint typically forces trees to preferentially spread roots laterally across the soil profile in order to compensate for the lack of anchorage usually obtained through deeper root penetration (Nicoll et al. 2005; Gallaway et al. 2009). Exploring this possibility further, the average root plate depth of tree throws at each mapped site was correlated against the number of fallen trees per site using a Pearson Correlation test, again, performed at the $95 \%$ confidence level. A significant indirect relationship between the two variables (Pearson $r=-0.552 ; P<0.05 ; n=12)$ indicated that tree throws were more common at sites where root depth was shallow. As mapped tree throw sites were of unequal 
areas, average root plate depth for each site was correlated against the number of equivalent tree throws per hectare. The result of this additional test, again, performed at the $95 \%$ confidence level, revealed no significant relationship between the two variables. Despite the lack of a significant relationship, and by way of explanation, however, we cautiously posit that applying the statistical approach at the hectare-scale may possibly mask the effect of localised, or small-scale, variations in soil profile depth.

As almost $50 \%$ of mapped tree throws in our 12 study sites were between 31-50 years old at the time upheave occurred (Fig. 4), we surmise that trees of this age group and older probably reach a critical threshold in terms of their height, mass and centre of gravity (Ramos-Sharrón and MacDonald 2007) which renders them susceptible, presumably to root failure on the steep, rocky terrain commonly found in Kaltbrunnental catchment. The possibility of large numbers of trees in close proximity all experiencing sudden upheave was noted by Hellmer et al. (2015), who attributed the 'clustering' effect to an apparent build-up of 'susceptibility', caused by factors which, they surmise, include the density of trees in a given area, numbers of already deceased trees, localised slope gradient, and age, size, and predominant species-type. A possible reason for this somewhat paradoxical finding may relate to the cascade effect noted by Hellmer et al. (2015), whereby tree throw often occurs in clusters, with many trees being upheaved in close proximity to each other.

\subsection{Effect of wind on tree throw}

The effect of wind on tree throw could not be statistically tested due to an absence of wind direction data at the necessary spatial and temporal resolutions, and the likelihood that localised topography might also have influenced wind speed and direction by deflecting prevailing winds (e.g. Ruel et al. 1998). However, as the direction of tree failure during winddriven storm events tends to align with predominant wind direction (Gallaway et al. 2009), the fall-angle of individual tree throws in this catchment was used as a proxy to indicate the role that prevailing winds may or may not have played in their upheave ( $c f$. Ruel et al. 1998; Hellmer et al. 2015). In order to explore this possibility more thoroughly, GIS was used to determine hillslope aspect of the 12 surveyed areas, which were then sub-divided into four cardinal groups; namely north, south, east and west. The fall direction of individual tree throws on each hillslope site (expressed in degrees) was then determined, again, with $\mathrm{O}^{\circ}$ representing the most direct downslope route to the river, and $180^{\circ}$ representing directly upslope. This approach, which can be seen in Fig. 6, followed the rationale that if fall direction was initiated or controlled by prevailing winds during Storms Lothar and Martin, the orientation of all fallen trees would be generally similar. Interrogating data presented in Fig. 6 more closely reveals that notable numbers of tree throws fell at an angle of $\mathrm{O}^{\circ}$, or directly downslope towards the Ibach river (Table 4).

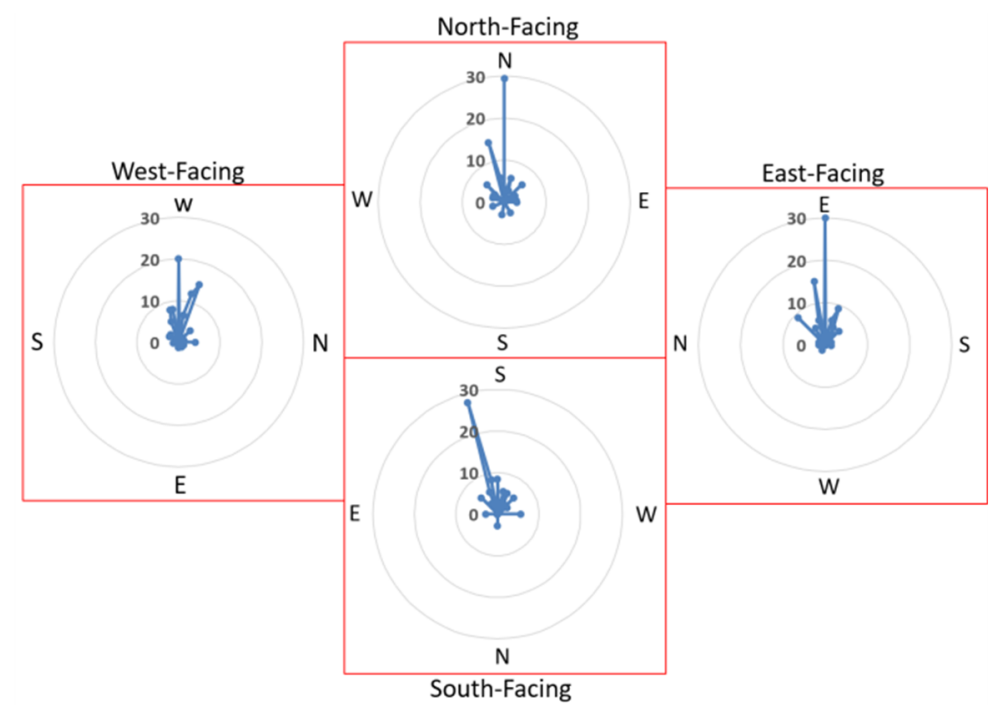

Fig. 6 Percentage proportions of individual tree throw fall directions, relative to the four main hillslope aspects: north $(\mathrm{N})$, south (S), east (E), and west (W), on which they were mapped. 
Table 4 Numbers of tree throws falling at $\mathrm{O}^{\circ}$, expressed as $\%$ of total number of tree throws, relative to the hillslope aspect on which they were mapped.

\begin{tabular}{ll|l|l}
$\begin{array}{l}\text { Hillslope } \\
\text { aspect }\end{array}$ & $\begin{array}{l}\text { Total tree throw } \\
\text { numbers }\end{array}$ & $\begin{array}{l}\text { Tree throw } \\
\text { falling } 0^{\circ}\end{array}$ & $\begin{array}{l}\text { Tree throw } \\
(\%)\end{array}$ \\
\hline North & 34 & 10 & 29 \\
South & 36 & 3 & 8 \\
East & 70 & 21 & 30 \\
West & 75 & 15 & 20 \\
Total & 215 & 49 & 23
\end{tabular}

In terms of absolute numbers, fallen trees situated on east-facing hillslopes recorded the highest proportion at $32 \%(21 ; n=70)$, followed by the north-facing slopes at $29 \%(10 ; n=34)$, and $20 \%(15 ; n=75)$ on west-facing slopes. The exception to this general trend was on south-facing slopes where only 8\% (3) of all mapped tree throws $(n=36)$ fell at $0^{\circ}$. If the range of fall direction is expanded to between $345^{\circ}-20^{\circ}$, however, $66.5 \%(143 ; n=215)$ of all mapped tree throws fell towards the river (i.e. directly downslope), irrespective of the hillslope aspect on which they were located. These findings not only question whether individual high-magnitude storms, such as Lothar and Martin, acted as a trigger in initiating tree throw, certainly in this particular catchment ( $c f$. Bründl and Rickli 2002), but instead opens the possibility that root failure leading to tree throw could actually be initiated by relatively low-magnitude storm events which take place more regularly. Although somewhat anecdotal, this possibility is supported by ca. 150 separate site visits undertaken by the $1^{\text {st }}$ author (Greenwood) over a ca. 6-year period, where it was observed that tree throw in this catchment seemed to operate as an almost quasi-continuous process, and irrespective of whether a high-magnitude storm had occurred or not. In light of previous research demonstrating that $30 \%$ less force is required to induce downslope root failure than equivalent upslope root failure (Nicoll et al. 2005), we tentatively attribute the prevalent downslope fall direction to reduced root anchorage. Whilst a lack of data on specific wind direction means that upheave by wind during single, high-magnitude storm events such as Lothar or Martin cannot be entirely dismissed, we hypothesise that the presence of bedrock close to the surface of steeper slopes, combined with a shallow soil profile (Lutz 1960; Mills 1984; Ruel 2000) may represent contributory factors to their upheave. From the frequent observations of recent upheaved trees, and based on our data, these lead us to further tentatively hypothesise that perhaps once trees in this catchment attain a certain age, and hence, a certain size and height, the ability of the tree to remain upright and stable appears to be compromised (Gabet et al. 2003); to the point where the height/mass, and increasingly elevated centre of gravity associated with larger trees all conspire to render them vulnerable to upheave (Rich et al. 2007).

\subsection{Sediment transport rates: a comparison with other relevant studies}

Table 5 lists key findings from three similar studies for the purpose of comparing and contrasting equivalent values obtained in this investigation, although we acknowledge that their sediment transport estimates include both fine and coarse sediment. With regard to the spatial extent of study sites, despite our investigation surveying the smallest area (cumulative $5.3 \mathrm{ha}$ ), and mapping the lowest total number of tree throws (215), we recorded the highest average equivalent tree throw density per hectare (Table 2). Given that $>70 \%$ of mapped tree throws in our river valley were $\geq 31$ years old at the time upheave occurred, the larger stature associated with more mature trees suggests, again, that they probably reach a critical threshold in terms of their height and mass, which when exceeded, renders them vulnerable to root failure and sudden upheave. We

Table 5 A comparison of key findings among four similar tree throw studies. It should be noted, however, that estimated sediment transport in this investigation only includes data for the fine sediment fraction and therefore likely underestimates actual sediment transport.

\begin{tabular}{|c|c|c|c|c|}
\hline Parameter & $\begin{array}{l}\text { Gallaway et al. } \\
\text { (2009) }\end{array}$ & $\begin{array}{l}\text { Hellmer et al. } \\
\text { (2015) }\end{array}$ & $\begin{array}{l}\text { Strzyzoqski et al. } \\
\text { (2018) }\end{array}$ & $\begin{array}{l}\text { This Investigation } \\
\text { (2018) }\end{array}$ \\
\hline Modeled time since tree throw event (yrs.) & 32 & 20 & 48 & 18 \\
\hline Area mapped/surveyed (ha) & 9.8 & 108 & 21,160 & $5 \cdot 3$ \\
\hline Numbers of mapped tree throws & 319 & 643 & 252 & 215 \\
\hline Tree throw density $\left(h^{-1}\right)$ & 33 & 6 & 0.01 & 43 \\
\hline Fine-sediment as proportion total root plate (\%) & $0-75$ & $25-50$ & 100 & 25 \\
\hline Estimated sediment transport rate $\left(\mathrm{m}^{3} \mathrm{~m}^{-1} \mathrm{yr}^{-1}\right)$ & $1.2 \times 10^{-3}$ & $2.3 \times 10^{-5}$ & $2.76 \times 10^{-5}$ & $2.7 \times 10^{-5}$ \\
\hline
\end{tabular}


tentatively attribute this possibility to the characteristically steep hillslopes in our study catchment, where steeply convex slopes and the presence of bedrock close to the surface exerts a control that is proportional to sediment flux, which constrains the depth of the soil profile, as initially reported by Dietrich et al. (1982), and more recently, confirmed by Heimsath et al. (1997). The nature of the terrain may also explain why upheaved trees $\geq 71$ yrs. old only accounted for $4.7 \%(n=10)$ of our mapped tree throw dataset.

In terms of annual sediment transport rates, three studies calculated values in the order of $10^{-5} \mathrm{~m}^{-1}$ $\mathrm{yr}^{-1}$ (Table 5). The exception to this was Gallaway et al. (2009), who recorded transport rates in the order of $10^{-3} \mathrm{~m}^{-1} \mathrm{yr}^{-1}$. As slope gradient, fall direction and sediment generation volumes documented in their investigation were comparable with the three other studies listed in Table 5, reasons for their notably higher rate of transport are unclear, but may have arisen due to the integration of a complex modelling component dealing with tree population dynamics. Noteworthy between the four studies, however, are differences in estimates of the proportion of finesediment associated with total root plate volume. Despite Gallaway et al. (2009) determining the proportion on a case-by-case basis in increments ranging from $0 \%-75 \%$, estimates from the four studies range from a liberal 100\% (Strzyżowsk et al. 2018), to a cautious $25 \%$ (this study). As the proportion of finesediment estimated by us represents the most conservative of the four values, our preliminary assessment of sediment generation rates may be overly cautious and hence, transport rates may be underestimated; the likelihood of which is further elevated since the coarse sediment fraction was not included in our calculations.

\section{Conclusion}

The results from this preliminary assessment of sediment-generation potential by tree throw and the subsequent degradation of soil mounds associated with tree throws in a small river valley of the Jura Mountain range suggests that both mechanisms represent an important driver of hillslope processes that warrant more detailed investigation. Information on surface hydrology characteristics of four fresh soil mounds associated with recent tree throws revealed, over a 24-day monitoring period, high sediment yields and very high equivalent SSC values, despite \% runoff coefficients being exceptionally low. These findings are collectively interpreted as evidence that degradation processes other than surface runoff are more dominant in eroding fresh soil mounds. Reasons for this are attributed to the loose, uncompacted nature of the soil from which fresh soil mounds are formed, the characteristics of which promote infiltration of surface water, which inhibits runoff generation. Based on the average $0.14 \mathrm{~mm}$ denudation rate recorded by us over the 24-day period, equivalent to $2.1 \mathrm{~mm} \mathrm{yr}^{-1}$, we estimate that a $500 \mathrm{~mm}$ high soil mound could theoretically persist in this catchment for around 200-250 years.

For logistical and practical reasons, we could not estimate the coarse sediment fraction associated with a given root plate volume. Consequently, the $25 \%$ proportion of the total root plate volume attributed by us solely to fine-sediment thus represents an underestimate of the actual total sediment disturbance, if all size fractions were included. Given this potential shortcoming in our investigative methodology, a more comprehensive approach in future would be to determine the proportions of both coarse and fine-sediment fractions for an individual tree throw on a case-by-case basis, in order to obtain a more representative estimation that takes into account total sediment disturbance. For the finesediment fraction ( $<2 \mathrm{~mm}$ diameter), however, tree throws detached and thus generated a total of $20.1 \mathrm{~m}^{3}$, or the equivalent of $3.8 \times 10^{-4} \mathrm{~m}^{3} \mathrm{~m}^{-2}$.

The process of tree throw was originally attributed to two extreme weather events that occurred in west and central Europe in late December 1999. Taking the 18-year period since both storms, this represents an annual sediment transport rate of $2.7 \times 10^{-5} \mathrm{~m}^{3} \mathrm{~m}^{-1} \mathrm{yr}^{-1}$. Despite originally attributing all tree throws to Storms Lothar and Martin, based on tree throw fall direction, our interpretations of the available data suggest that their orientation was generally independent of hillslope aspect for the majority of fallen trees that we were able to document. Consequently, the original assumption that Storms Lothar and Martin played a major role in initiating tree throw may be incorrect, but cannot be entirely dismissed without the benefit of historic, localised wind direction data, which is not available. Instead, given the number of high-density areas of tree throws in this river valley, their relative maturity (av. age 41 
yrs.), and the fact that tree throw tended to occur in clusters, we believe groups of trees within a certain age-range may become susceptible to upheave. Reasons for their heightened susceptibility to upheave may be due to the larger stature associated with older trees, which gradually renders them increasingly unstable and eventually compromises their ability to remain securely anchored on the type of terrain encountered along the Ibach river valley. We attribute this to the inherently steep slopes and to the presence of bedrock close to the surface, both of which limit the depth of soil profile.

\section{Acknowledgements}

This study was funded by the Physical Geography and Environmental Change Research Group, Department of Environmental Sciences, University of

\section{References}

Bobrovsky MV, Lyko SV (2016) Patterns of pedoturbation by tree uprooting in forest soils. Russ J Ecosyst Ecol 1: 1-22. https://doi.org/10.21685/2500-0578-2016-1-3

Bründl M, Rickli C (2002) The storm Lothar 1999 in Switzerland - an incident analysis. For Snow Landsc Res 77: 207-216.

https://www.dora.lib4ri.ch/wsl/islandora/object/wsl:15318

Constantine JA, Schelhaas MJ, Gabet E, Mudd SM (2012) Limits of windthrow-driven hillslope sediment flux due to varying storm frequency and intensity. Geomorphology 175176: 66-73.

http://doi.org/10.1016/j.geomorph.2012.06.022

Deletic A (2005) Sediment transport in urban runoff over grassed areas. J Hydrol 301: 108-122.

https://doi.org/10.1016/j.jhydrol.2004.06.023

Denny C, Goodlet J (1956) Micro-relief resulting from fallen trees. Surficial Geology and Geomorphology of Potter County, Pennsylvania, Professional Paper 288: 59-66

Dietrich W, Dunne T, Humphrey NF, Reid LM (1982) Construction of sediment budgets for drainage basins. In: Swanson FJ, Janda RJ, Dunne T, Swanston DN (eds.). Sediment budgets and routing in forested drainage basins. USDA For Serv Gen Tech Rep PNW-141.

EQE Consulting (2020) EQE Summary Report: The European Storms Lothar and Martin, December 26-28, 1999. EQE International Consulting: Strategic Advisors for Natural Hazards and Terrorism.

http://www.absconsulting.com/resources/Catastrophe_Repo rts/Lothar-Martin Report.pdf (accessed 05.03.2020)

Federal Office of Meteorology and Climatology MeteoSwiss (2014) Climate of Switzerland.

http://www.meteoswiss.admin.ch/home/climate/past/climat e-of-switzerland (accessed 08.09.2017)

Evarham EM, Brokaw NVL (1996) Forest damage and recovery from catastrophic wind. Bot Rev 62: 113-185.

https://doi.org/10.1007/BFo2857920

Fryirs KA, Brierly GJ, Preston NJ, Kasai M (2007) Buffers, barriers and blankets: The (dis)connectivity of catchmentscale sediment cascades. Catena 70: 49-67.
Basel. We declare no conflict of interest. The authors thank A. Hügli and B. Thommen, the Bürgergemeinde (Community Mayor) from the towns of Brislach (Canton Basel-Land) and Himmelried (Canton Solothurn), respectively, for granting access to the study catchment. Special thanks are also extended to the journal editors for their help and encouragement, and to three anonymous reviewers for their thoughtful comments and suggestions, all of which served to strengthen the paper.

Open Access This article is distributed under the terms of the Creative Commons Attribution 4.0 International License (http://creativecommons. org/licenses/by/4.0/), which permits unrestricted use, distribution, and reproduction in any medium, provided you give appropriate credit to the original author(s) and the source, provide a link to the Creative Commons license, and indicate if changes were made. https://doi.10.1016/j.catena.2006.07.007

Gabet EJ, Mudd SM (2010) Bedrock erosion by root fracture and tree throw: a coupled biogeomorphic model to explore the humped soil production function and the persistence of hillslope soils. J Geophys Res 115: 1-14.

https://doi.10.1029/2009JFo01526

Gabet EJ, Reichman OJ, Seabloom EW (2003) The effects of bioturbation on soil processes and sediment transport. Annu Rev Earth Planet Sci 31: 249-273.

https://doi.10.1146/annurev.earth.31.100901.141314

Gallaway JM, Martin YE, Johnson EA (2009) Sediment transport due to tree root throw: integrating tree population dynamics, wildfire and geomorphic response. Earth Surf Process Landf 34: 1255-1269. https://doi.10.1002/esp.1813

Geißler C, Kühn P, Böhnke M, et al. (2012) Splash erosion potential under tree canopies in subtropical SE China. Catena 91: 85-93.

https://doi:10.1016/j.catena.2010.10.009

Greenwood P, Baumann P, Pulley S, Kuhn NJ (2018) The invasive alien plant, Impatiens glandulifera (Himalayan Balsam), and increased soil erosion: causation or association?: case studies from a river system in Switzerland and the UK. Special Issue $14^{\text {th }}$ International Association of Sediment Water Sciences. J Soils Sediments.

https://doi.org/10.1007/s11368-018-2041-o

Greenwood P, Gange AC, Kuhn NJ (2019) Evidence of sedimentation inequality along riparian areas colonised by Impatiens glandulifera (Himalayan Balsam). Weed Res 60: 26-36.

https://doi.org/10.1111/wre.12397

Greenwood P, Kuhn NJ (2014) Does the invasive plant, Impatiens glandulifera, promote soil erosion along the riparian zone? An investigation on a small watercourse in northwest Switzerland. J Soils Sediments 14: 637-650. https://doi.org/10.1007/s11368-013-0825-9

Greenwood P, Zhang Y (2020) Comparing grain size composition of inter-rill and rill-eroded sediment from cultivated hillslope soils using caesium-134 and cobalt-6o as 
tracers. Soil Tillage Res 198

https://doi.org/10.1016/jstill.2019.104532

Hayhoe HN, Pellatier RG, Van Vliet AJP (1993) Estimation of snowmelt runoff in the Peace River region using a soil moisture budget. Can J Soil Sci 73: 489-501.

https://doi.org/10.4141/cjss93-050

Heimseth AM, Dietrich WE, Nishiizumi K, Finkel RC (1997) The soil production function and landscape equilibrium. Nature 388: 358-361.

https://doi.org/10.1038/41056

Hellmer MC, Rios BA, Ouimet WB, Sibley TR (2015) Ice storms, tree throws, and hillslope sediment transport in northern hardwood forests. Earth Surf Process Landf 40: 901-912. https://doi.10.1002/esp.3690

Horowitz AJ, Stephens VC, Elrick KA, Smith JJ (2012) Concentrations and annual fluxes of sediment associated chemical constituents from conterminous UK coastal rivers using bed sediment data. Hydrol Process 26: 1090-1114. https://doi.org/10.1002/hyp.8437

Kinnell PIA (2005) Raindrop-impact-induced erosion processes and prediction: a review. Hydrol Process 19: 2815-2844. https://doi.org/10.1002/hyp.5788

Ledermann $\mathrm{T}$, Herweg K, Liniger $\mathrm{H}$, et al. (2008) Erosion damage mapping: Assessing current soil erosion damage in Switzerland. Adv GeoEcol 39. p 263. Dazzi C \& Costantini E (eds.), ISBN 978-3-923381-56-2.

Lutz HJ (1940) Disturbance of forest soil resulting from the uprooting of trees. Yale University, School of Forestry Bulletin No. 45, Yale University: New Haven, CT. pp 1-37.

Martin YE, Johnson EA, Chaikina O (2013) Interplay between field observations and numerical modelling to understand temporal pulsing of tree root throw processes, Canadian Rockies, Canada. Geomorphology 200: 89-105. https://doi.org/10.1016/j.geomorph.2013.04.017

Martin YM (2000) Modelling hillslope evolution: linear and nonlinear transport relations. Geomorphology 34: 1-21. https://doi.10.1016/s0160-555x(99)00127-0

Martin YM, Church M (1997) Diffusion in landscape development models: on the nature of basic transport relations. Earth Surf Process Landf 22: 273-279.

https://doi.org/10.1002/(SICI)10969837(199703)22:3<273::AID-ESP755>3.0.CO;2-D

Meteoblue (2017) Climate Grellingen. https://www.meteoblue.com/en/weather/forecast/modelcli mate/grellingen_switzerland 2660513 (accessed 08.09.2017)

Mills HH (1984) Effect of hillslope angle and substrate on tree tilt, and denudation of hillslopes by tree fall. Phys Geogr 5 : 253-261.

https://doi.org/10.1080/02723646.1984.10642257

Mitchell AF (1974) A Field Guide to the Trees of Britain and Northern Europe. Collins Publishers.

Mitchell SJ (2013) Wind as a natural disturbance agent in forests: a synthesis. Forestry 86: 147-157.

https://doi.org/10.1093/forestry/cpso58

Nicoll BC, Achim A, Mochan S, Gardiner BA (2005) Does steep terrain influence tree stability? A field investigation. Can J For Res 35: 2360-2367. https://doi.org/10.1139/x05-157

Norman SA, Schaetzl RJ, Small TW (1995) Effect of slope angle on mass movement by tree uprooting. Geomorphology 14: 1927.

https://doi.org/10.1016/0169-555X(95)ooo16-X
Osterkamp WR, Toy TJ, Lenart MT (2006) Development of partial rock veneers by root throw in a subalpine setting. Earth Surf Process Landf 31: 1-14.

https://doi.org/10.1002/esp.1222

Pawlik $€$ (2013) The role of trees in the geomorphic system of forested hillslopes - A review. Earth-Sci Rev 126: 250-265. https://doi.org/10.1016/j.earscirev.2013.08.007

Peltola H, Kellomäki S, Väisänen H, Ikonen VP (1999) A mechanistic model for assessing the risk of wind and snow damage to single trees and stands of Scots pine, Norway spruce, and birch. Can J For Res 29: 647-661. https://doi:10.1139/x99-029

Putz F (1983) Treefall pits and mounds, buried seeds, and the importance of soil disturbance to pioneer trees on Barro Colado Island, Panama. Ecology 64: 1069-1074. https://doi.org/10.2307/1937815

Ramos-Sharrón CE, MacDonald LH (2007) Measurement and prediction of natural and anthropogenic sediment sources, St John, U.S. Virgin Islands. Catena 71: 250-266. https://doi.org/10.1016/j.catena.2007.03.009

Rich RL, Frelich LE, Reich PB (2007) Wind-throw mortality in the southern boreal forest: effects of species, diameter and stand age. J Ecol 95: 1261-1273. https://doi.org/10.1111/j.1365-2745.2007.01301.x

Rickli C, Graf F (2009) Effects of forests on shallow landslides Case studies in Switzerland. For Snow Landsc Res 82: 33-44. https://www.dora.lib4ri.ch/wsl/islandora/object/wsl:15351

Roering JJ, Marshall J, Booth AM, et al. (2010) Evidence for biotic controls on topography and soil production. Earth Planet Sci Lett 298: 183-190. https://doi.org/10.1016/j.epsl.2010.07.040

Ruel JC (2000) Factors influencing windthrow in balsam fir forests: from landscape studies to individual tree studies. For Ecol Man 135: 169-178. https://doi.org/10.1016/So378-1127(0o)00308-X

Ruel JC, Pin D, Cooper K (1998) Effect of topography on wind behaviour in a complex terrain. Forestry 71: 261-265. https://doi.org/10.1093/forestry/71.3.261

Šamonil P, Král K, Hort L (2010) The role of tree uprooting in soil formation: a critical literature review. Geoderma 157: 6579. https://doi.org/10.1016/j.geoderma.2010.03.018

Šamonil P, Scheatzl RJ, Valtera M, et al. (2013) Crossdating of disturbances by tree uprooting: Can three throw microtopography persist for 6000 years? For Ecol Manage 307: 123-135 http://doi.org/10.1016/j.foreco.2013.06.045

Schaetzl RJ, Burns SF, Johnson DL, Small TW (1988) Tree uprooting: review of impacts on forest ecology. Vegetatio 79: 165-176.

https://doi.org/10.1007/BFooo44908

Schweingruber FH (2007) Wood Structure and Environment. Springer Series in Wood Science. Springer Publishing, Heidelberg.

Strzyżowski D, Fidelus-Orzechowska J, Żelazny M (2018) Sediment transport by uprooting in the forested part of the Tatra Mountains, southern Poland. Catena 160: 329-338. http://doi.org/10.1016/j.catena.2017.09.019

Walling DE, Owens PE, Carter J, et al. (2003) Storage of sediment-associated nutrients and contaminants in river channel and floodplain systems. Appl Geochem 18: 195-220. https://doi.org/10.1016/So883-2927(02)00121-X 